\title{
Knowledge, Attitude and Practices Used in the Control of Striga in Maize by Smallholder Farmers of Western Kenya
}

\author{
Godfrey Nakitare Nambafu ${ }^{1,2}$, Richard Ndemo Onwonga ${ }^{1}$, George Njomo Karuku ${ }^{1}$, Emmanuel Safaris Ariga ${ }^{3}$, \\ Bernard Vanlauwe ${ }^{2}$ and Kristina Roing de Nowina ${ }^{2,4}$ \\ 1. Department of Land Resource Management and Agricultural Technology, University of Nairobi, Nairobi 29053, Kenya \\ 2. International Institute of Tropical Agriculture (IITA), Nairobi 30772-00100, Kenya \\ 3. Department of Plant Science and Crop Protection, University of Nairobi, Nairobi 29053, Kenya \\ 4. Department of Soil and Environment, Swedish University of Agricultural Science, Uppsala 7070, SE-750 07, Sweden
}

Received: Novermber 8, 2013 / Published: March 20, 2014.

\begin{abstract}
The production of maize is constrained by parasitic weeds, particularly Striga. A study was carried out to document farmers' knowledge, attitude and practices on Striga control among smallholder farmers across three districts: Kisumu West, Busia and Teso South of Western Kenya. A multistage sampling technique was used to select the locations and farmers to be interviewed. A semi structured, open and closed ended questionnaire was administered leading to field experiment. Besides village meetings (39.2\%), farmers got informed on farming methods under Striga weed farms and its control technologies through neighbours (2.5\%), workshops and trainings (5.0\%), field schools (3.7\%), media (7.5\%) and extension agents (10.8\%). The attitudes of farmers towards Striga control varied but frequently cited: long term viability of the Striga seed (12.5\%), difficult to control sharing of farm tools (10.8\%), expensive technologies (13.3\%), lack of adequate information (18.3\%), labour intensive (15.0\%), large farms for use of push and pull technology (1.7\%) and time consuming (12.5\%). Framers used various Striga control practices but traditional methods (25\%) were among the most used (25\%). Concerted effort involving researchers, extension agents and private sector are, therefore, required for wide scale dissemination and adoption of the existing modern control technologies.
\end{abstract}

Key words: Attitude, knowledge, practice, striga control technologies.

\section{Introduction}

Maize, a staple food for most households in Kenya, is grown on both large and small-scale farms in almost all agro-ecological zones. Smallholder farmers take over $80 \%$ of the land under maize but produce over $70 \%$ of the total production [1]. Average farm sizes for maize production continue to shrink due to increasing rural population. This consequently negatively affects the production of maize. Production is also constrained by low soil fertility due to continuous

Corresponding author: Godfrey Nakitare Nambafu, M.Sc., research fields: social economics and Striga weed control. E-mail: nambafugodfrey@gmail.com. cropping [2] and nitrogen deficiency [3] with no replenishment of mined nutrients. This is in addition to pests such as stem borers and parasitic weeds, particularly Striga [4, 5].

Striga weed hinders the efforts to attain food security and economic growth in the continent. Nearly 300 million people in sub-Saharan Africa are adversely affected by Striga weed, and up to 50 million hectares of crop lands in the continent show varying degrees of Striga infestation [6]. Striga weed infestation causes $30 \%-100 \%$ loss in maize yield in Eastern Africa [7-9]. In Kenya, Striga weed infestation is most severe in Siaya, Vihiga and Busia Counties. The parasitic weed 
is found in about 75,000 hectares of farmland and results in crop losses estimated at about US\$10-38 million per annum [10]. Lately, yield losses of over $80 \%$ have been attributed to Striga weed [11]. As a result, some farmers abandoned their fields or switched to production of other crops such as cassava and sweet potatoes [12].

In response to the threat and effects of the weed, several methods of Striga weed control have been developed but farmers have not adopted them to any appreciable extent [5, 13]. The reasons for non-adoption include poor farmers' economic conditions which are below the cost of the required Striga control technologies together with the non-availability of economically feasible and effective technologies that are adapted to these conditions [14]. Besides the efficacy of a technology, the severity of existing constraints determines the decision to invest in a technology [15, 16]. Against this back drop, an evaluation of farmers' knowledge, attitude and practices on Striga weed control techniques among smallholder farmers of Western Kenya was conducted for informed dissemination and subsequent adoption of new Striga control technologies.

\section{Materials and Methods}

The study was conducted in Kisumu West, Busia and Teso South districts of Western Kenya. The districts fall under ecological zone IV [17]. The three districts have slightly varying climatic conditions with annual rainfall ranging between $800 \mathrm{~mm}$ to $2,000 \mathrm{~mm}$, average temperatures range between $14{ }^{\circ} \mathrm{C}$ and $34{ }^{\circ} \mathrm{C}$ in January and $14{ }^{\circ} \mathrm{C}$ and $30{ }^{\circ} \mathrm{C}$ in July, altitude range between $1,216 \mathrm{~m}$ and $1,520 \mathrm{~m}$. The soil varies across the region and comprises of Ferralsols (Busia), Vertisols (Kisumu West) and Nitosol (Teso South) [18]. A multi-stage sampling technique was applied to select the study sites that represent diverse ecological and socio-economic conditions and varying farming systems in the moist mid-altitude districts. This involved selecting a district, then narrowed down to a division, keeping in mind that the divisions selected should be highly infested with Striga than others. At the division level, also a district heavily populated with striga was considered. At that point, the villages and the farmers to be interviewed were randomly selected. The sampling size was done by proportion in line with the population size of the location based on Cochrane formulae [19]. A total of 120 farmers were interviewed using a semi structured questionnaire in the study. Data collected from the field were edited (reviewing data, completeness checking and error detection) and coded then analysed for means, descriptive statistics, correlations and tables, using SPSS, Version 17.0. Chi square test at $P<0.05$ was applied to determine the relationship between measured parameters.

\section{Results and Discussion}

\subsection{Demographic Characteristics}

There were similarities of responses among the farmers across the districts in relation to age, sex of the household, marital status and occupation (Table 1). About $68.3 \%$ of the farmers interviewed practiced farming as the main economic activity. Mixed farming was the dominant farming system in the districts. The farming fraternity was evenly distributed across the district but Kisumu West showed many (12.5\%) being employed. This was due to existence of institutions and organizations at Maseno town and Kisumu city that provided room for employment. This is also in agreement with a past survey conducted in Ref. [20], who found that most households (about 76\%) in the study areas were farmers.

Most of those practicing farming fell between ages of 36-55 years old, comprising of $48.3 \%$, whereas $36.7 \%$ are aged between 18-35 years old, and 15\% above 55 years old. Busia district had the largest number of those from 36-55 years old and Kisumu district showed those with 18-35 years old being many. This shows that the youths were getting involved into farming unlike in the past where the majority of farmers were above 55 years. The youths 

by Smallholder Farmers of Western Kenya

Table 1 Percentages of farmer's occupation against their age and marital status in the districts.

\begin{tabular}{|c|c|c|c|c|c|c|c|c|c|c|}
\hline \multirow{2}{*}{\multicolumn{2}{|c|}{ Occupation and district }} & \multicolumn{3}{|c|}{ Age of respondent } & \multicolumn{5}{|c|}{ Marital status of HH head } & \multirow[t]{2}{*}{ Total } \\
\hline & & $18-35$ & $36-55$ & $>55$ & Married & Divorced & Widow & Widower & Single & \\
\hline \multirow{4}{*}{ Farmer } & Kisumu West & 6.7 & 8.3 & 3.3 & 15 & 0 & 5 & 0 & 0 & 20 \\
\hline & Busia & 7.7 & 13.3 & 5 & 20 & 0 & 5 & 0 & 0 & 25 \\
\hline & Teso South & 12.3 & 9.2 & 2.5 & 22.5 & 0 & 0.8 & 0 & 0 & 23.3 \\
\hline & Total & 26.7 & 30.8 & 10.8 & 57.5 & 0 & 10.8 & 0 & 0 & 68.3 \\
\hline \multirow{4}{*}{ Employed } & Kisumu West & 4.2 & 5 & 3.3 & 10.8 & 0 & 1.7 & 0 & 0 & 12.5 \\
\hline & Busia & 0 & 5 & 0 & 4.2 & 0 & 0 & 0 & 0.8 & 5 \\
\hline & Teso South & 2.5 & 4.2 & 0 & 4.2 & 0.8 & 0.8 & 0 & 0.8 & 6.6 \\
\hline & Total & 6.7 & 14.2 & 3.3 & 19.2 & 0.8 & 2.5 & 0 & 1.7 & 24.2 \\
\hline \multirow{4}{*}{$\begin{array}{l}\text { Both farmer and } \\
\text { employed }\end{array}$} & Kisumu West & 0.8 & 0 & 0 & 0.8 & 0 & 0 & 0 & 0 & 0.8 \\
\hline & Busia & 0.8 & 0.8 & 0.8 & 2.5 & 0 & 0 & 0 & 0 & 2.5 \\
\hline & Teso South & 0.7 & 2.5 & 0 & 0.8 & 0.8 & 0.8 & 0.8 & 0 & 3.3 \\
\hline & Total & 2.5 & 3.3 & 0.8 & 4.2 & 0.8 & 0.8 & 0.8 & 0 & 6.6 \\
\hline \multirow{4}{*}{$\begin{array}{l}\text { Business } \\
\text { man/woman }\end{array}$} & Kisumu West & 0.8 & 0 & 0 & 0.8 & 0 & 0 & 0 & 0 & 0.8 \\
\hline & Busia & 0 & 0 & 0 & 0.8 & 0 & 0 & 0 & 0 & 0 \\
\hline & Teso South & 0.8 & 0 & 0 & 0 & 0 & 0 & 0 & 0 & 0.8 \\
\hline & Total & 1.6 & 0 & 0 & 1.6 & 0 & 0 & 0 & 0 & 1.6 \\
\hline \multirow{4}{*}{ Total } & Kisumu West & 13.3 & 13.3 & 6.7 & 26.7 & 0 & 6.7 & 0 & 0 & 33.3 \\
\hline & Busia & 8.3 & 19.2 & 5.8 & 27.5 & 0 & 5 & 0 & 0.8 & 33.3 \\
\hline & Teso South & 15.1 & 15.8 & 2.5 & 27.5 & 1.7 & 2.5 & 0.8 & 0.9 & 33.3 \\
\hline & Total & 36.7 & 48.3 & 15 & 81.7 & 1.7 & 14.2 & 0.8 & 1.7 & 100 \\
\hline
\end{tabular}

ought to be encouraged further since they were good in technology understanding, adoption and implementation. Most (81\%) of the households were married. There were more women headed household in Kisumu West district than in Busia and Teso South, as reflected by widowhood data. In a separate study, Manyong [21] reported that the highest number of female-headed households which was reported in Siaya district of Nyanza province could have been as a result of high incidence of HIV/AIDS and out-migration of youths. However, in this study, no data was available to attribute the high incidence of women headed households in Kisumu West to HIV/AIDS related widowhood.

In all districts, 58\% of the interviewed farmers were men and $42 \%$ were women giving a better representation of gender. This was a good indication that decisions on farming issues were mostly made by both couples but in case of widows and widowers, decision was by household heads. Thus, females were also involved in decision making at the house hold level. The past result by Ndufa et al. [22] shows that household heads were either monogamous or polygamous, i.e., $50 \%$ of the households were monogamous male-headed household, 16\% polygamous male-headed household, $4 \%$ female headed household absentee husband, 17\% monogamous female-headed household widow and $11 \%$ polygamous female-headed household widows in Western Kenya.

The study area showed that about $50 \%$ of the farmers had primary education, 35\% had acquired secondary education and $15.8 \%$ tertiary education. Only $3.3 \%$ of the farmers claimed to have never gone to school. Unlike the findings of Ndufa et al. [22] who found out that about $10 \%$ of the farmers were illiterate while the majority of the farmers had acquired primary education. This level of illiteracy has gone 
down due to the fact that the government has introduced free primary education to all forcing even the "old" people to seek education.

\subsection{Farming Activities of Farmers in Western Kenya}

The main crops grown were maize, sorghum, finger millet and beans with $92 \%$ of the farmers growing maize alone or alongside other crops (Table 2). The major cash crops were sugarcane and tobacco. Most crops were, however, grown as both cash and subsistence crops, but in most cases subsistence given that most farmers hold small farmers meant to grow crops to be consumed by the family. Studies in Refs. $[23,24]$ showed that the major cash crops are sugarcane, tobacco and cotton. Most of the other crops serve a dual purpose as cash and subsistence crops, but mainly subsistence. Also, Hearne [25] showed that maize was both subsistence and a commercial crop in Kenya grown on an estimated 1.4 million hectares by large-scale farmers (25\%) and smallholders (75\%).

Livestock kept were mainly indigenous cattle (64.2\%) and chicken. This is because the community recognizes their economic gain (milk and eggs). Other livestock kept included, sheep, goats and pigs. Earlier reports in Refs. [23, 24] also showed that livestock comprised mainly local breeds of cattle (zebus), chicken, sheep and goats pre-dominated the smallholder farming systems.

\subsection{Farmers' Knowledge on Striga Weed Control}

The farmers displayed unparallel led knowledge on Striga weed in regard to its life span, differences among the existing species, the host plants and Striga menace, although this was not captured in the questionnaire but was seen to be very important information to be discussed since it came from most of those farmers interviewed. This is mainly due to the long term prevalence and adverse effects of Striga weed in their farms. Ref. [21] showed that respondents had the correct perception about the damage Striga could cause to maize yield, the reasons could be the high incidence of pest and diseases in the sampled villages.

Farmers in the study sites mentioned various pathways of agricultural information and dissemination (Fig. 1) either at group levels or household level. Besides village meetings (45.9\%), farmers also got informed through neighbours (2.5\%), who were good implementers of technologies, through attending free workshops and trainings (5.0\%), field schools (3.3\%), media (7.5\%) from extension workers belonging to both international and local NGOs, Ministry of Agriculture and Kenya Agricultural Research Institute (10.8\%). This information trend cuts across the districts.

Village meetings were an important (45.9\%) source of information, probably because most people prefer attending these meetings than any other organized meetings that are held to discuss and address human rights and security issues with farming issues being relegated to the periphery. Little information was got from neighbours probably because of poor communication and the self-interest of farmers. Debrah et al. [14] also found that the major source of farmers knowledge on Striga was informal (personal observations, relatives, parents and other farmers) with only $10 \%$ of the farmers getting knowledge from formal sources (research, extension and media).

Most farmers (81\%) were aware of the mode of spread of Striga seeds and thus explained it easily. They identified the agents of Striga weed dispersion (Fig. 2) as: wind (25.8\%), animals (25\%), farm implements (10\%) and water runoff (6.7\%).

Water runoff was rated least because most farms have gentle slopes and hence experienced less soil erosion. Wind and animals dominated the dispersal means because farm crops are harvested at the time when the Striga weed had flowered and some at the seed forming process thus easily dispersed. Since, in grazing management animals are left to wander from one farm to another, they move along with the Striga seeds. The seeds that are not dispersed by animals are 

by Smallholder Farmers of Western Kenya

Table 2 Percentages of farmers growing crops, the purpose of crops and keeping animals in the districts.

\begin{tabular}{llllll}
\hline Crops & Percentage (\%) & Animals kept & Percentage (\%) & Purpose of growing maize & Percentage (\%) \\
\hline Maize & 92.0 & Cattle & 64.2 & Own consumption & 49.6 \\
Sorghum & 40.8 & Poultry/chicken & 83.3 & Commercial & 1.6 \\
Finger millet & 12.3 & Goat & 35.0 & Both consumption and commercial & 48.8 \\
Soybeans & 32.5 & Sheep & 20.8 & & \\
Common beans & 30.8 & Pig & 15.8 & & \\
Ground nuts & 1.8 & & & & \\
Tobacco & 3.5 & & & & \\
\hline
\end{tabular}

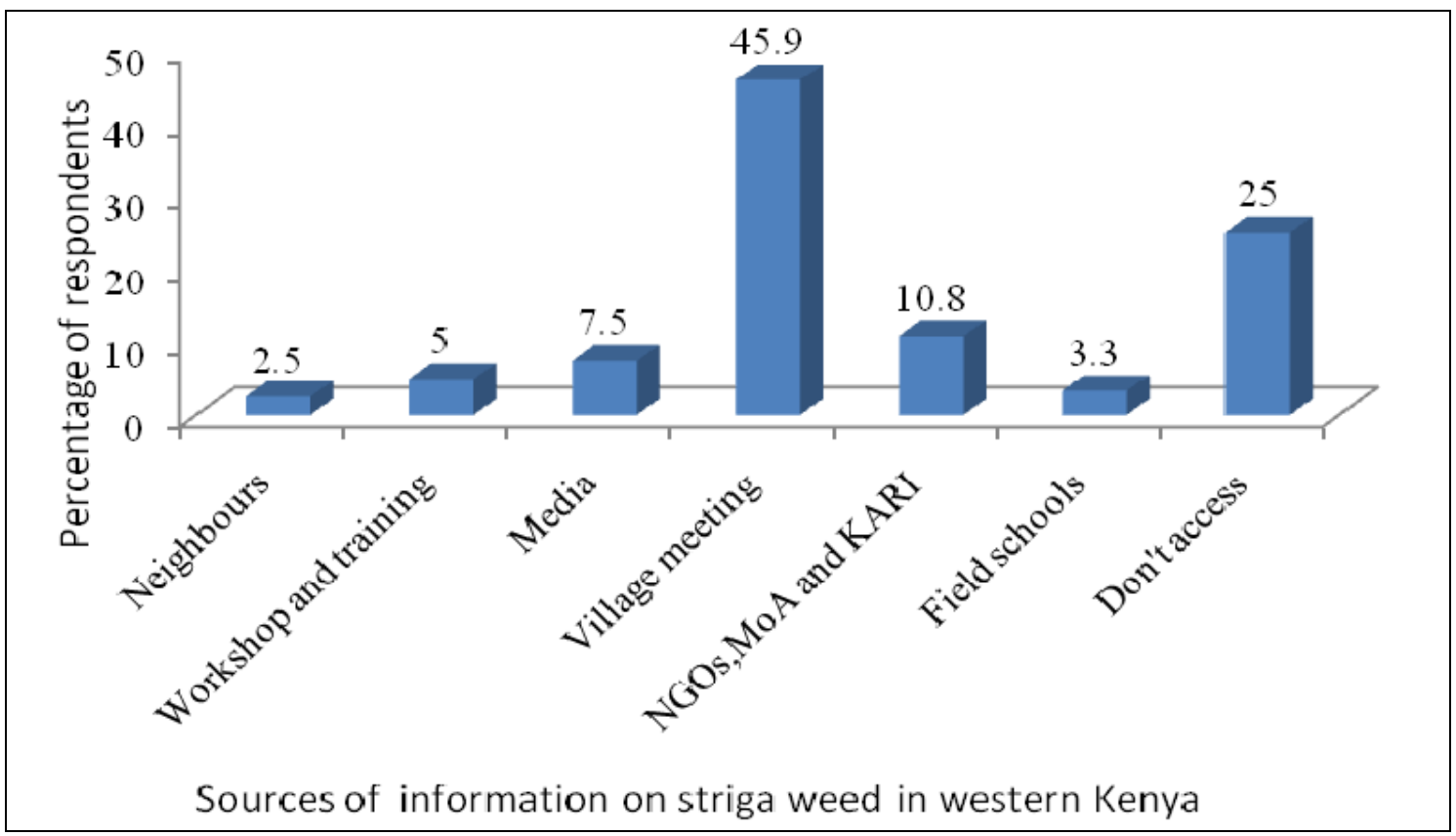

Fig. 1 Information sources on Striga weed control and technologies.

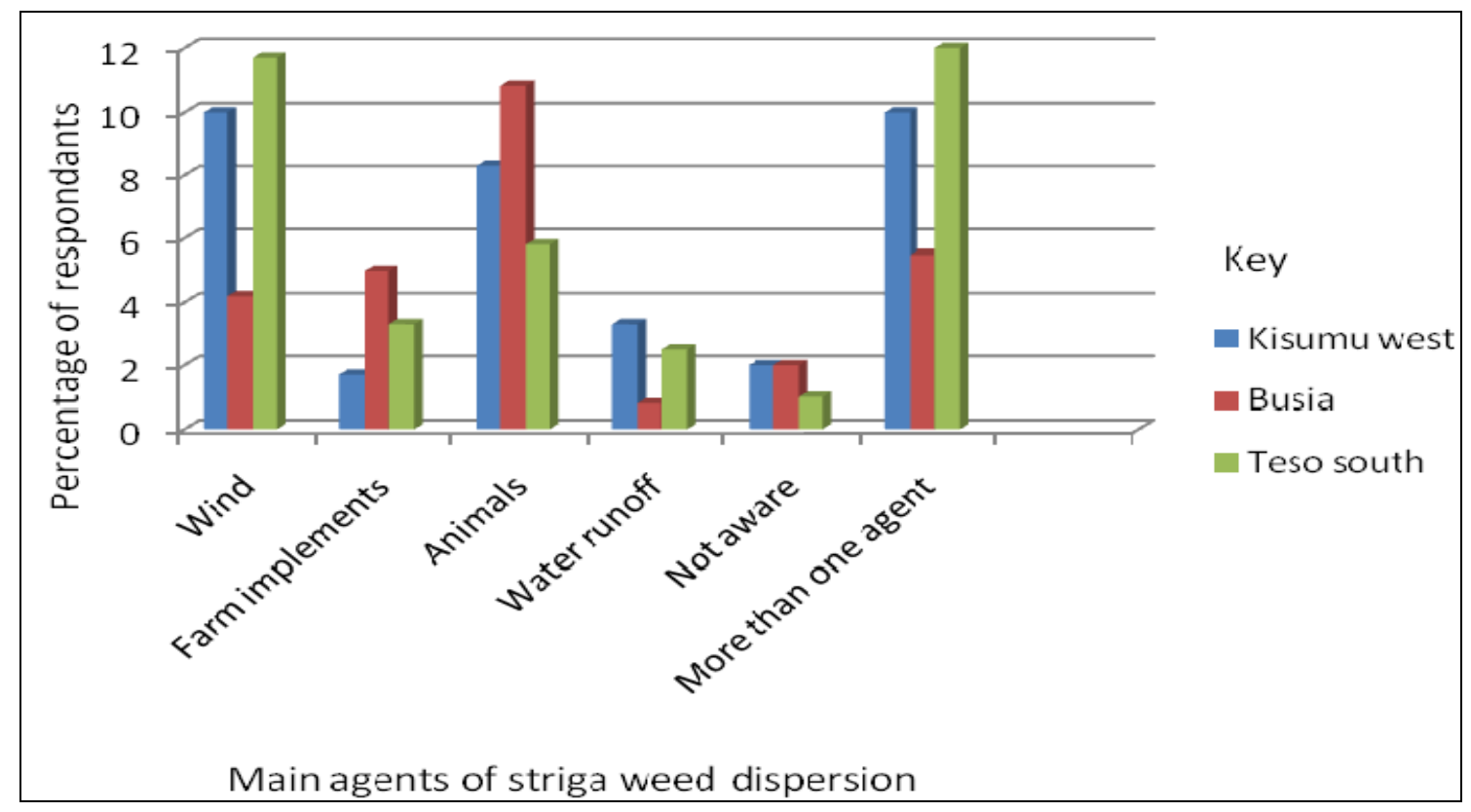

Fig. 2 Major Striga weeds dispersion modes in the districts of Western Kenya. 
usually blown by wind to the neighboring fields. Oswald [5] and Hearne [26] also found that the major agents of seed dispersal were human beings through tools used for land preparation and weeding and animals during grazing.

Most farmers belonged to social groups. It was noted that those who attended group meetings were better placed to get new information's regarding farming and other trainings. It is also through attending these group meetings that farmers arranged for study tours and sites for demonstration plots/field schools. Since men were reluctant to join social groups, they miss most of the information passed through the groups and yet they are the most dependable members of household on decision making.

A recent study by Odhiambo et al. [27] showed that women farmers learnt more willingly from men resource persons while men were reluctant to learn from women groups. It was further reported that men were more recognized as trainers than women, also they might have more available time for follow ups and consultations than women. Besides, women farmers registered higher adoption rates (70\%) compared to $30 \%$ in men [28]. Given that the illiteracy level was high, where majority (45\%) of farmers have gone up to primary level of education, the knowledge passed is forgotten easily before the farmer implements on the farm since no record or notes are taken and thus poor ways of implementation may be adopted.

\subsection{Farmers Attitude towards Striga Control Technologies}

Farmers ranked Striga hermonthica (72.1\%) as the first and soil fertility as second major hindrance to cereals production. This was followed by pests and diseases, input acquisition and lastly drought (Fig. 3).

Striga was ranked first as it comes with devastating effects that farmers have longed to overcome, among their yield losses. Study by Hassan et al. [29] showed that Striga was still the number one constraint for Western province while low and erratic rainfall was for Nyanza. Probably, the reason for the high ranking of this climatic factor in Nyanza was because the survey was conducted at the period when there was a severe drought.

Farmers attitude on Striga were differently expressed by the respondents (Fig. 4). Farmers understood that Striga weed seeds had a tendency of staying in the soil for longer periods before losing their viability and would sprout once a cereal (host plant) becomes available. This attitude is killing the efforts of $13 \%$, of the study population. Study by Odendo et al. [30] showed that the constraints reported were declining soil fertility, high Striga infestation and vagaries of weather (drought, unreliability and hailstones), poor infrastructure and poor marketing.

Lack of enough money to purchase farm implements such as hand hoe and ox-plough had necessitated $11 \%$ of the farmers to share farm tools with their close and even far away neighbours leading to the spread of the weed from one farm to the other. Ref. [1] showed that the most attitudes farmers develop in Striga control are in line with lack of farm tools, low soil fertility, lack of financial resources to purchase inputs and the active nature of Striga seed over time.

About $13 \%$ of the respondents noted that some technologies like push and pull and use of striga resistant maize were too expensive for small scale farmers. The cost can be traced right from the implementation stage to the final stage. Lack of adequate information (18\%) about specific technologies was another factor that contributed to the low technology adoption. Most of the information farmers needed existed but in forms farmers cannot access. As argued by Asfaw et al. [31] awareness in technology transfer is very important. In most of the adoption cases in developing countries, adoption is hampered by lack of awareness of the end users of the technologies. Farmers' awareness about the available improved varieties is, therefore, critical in the adoption programme. 


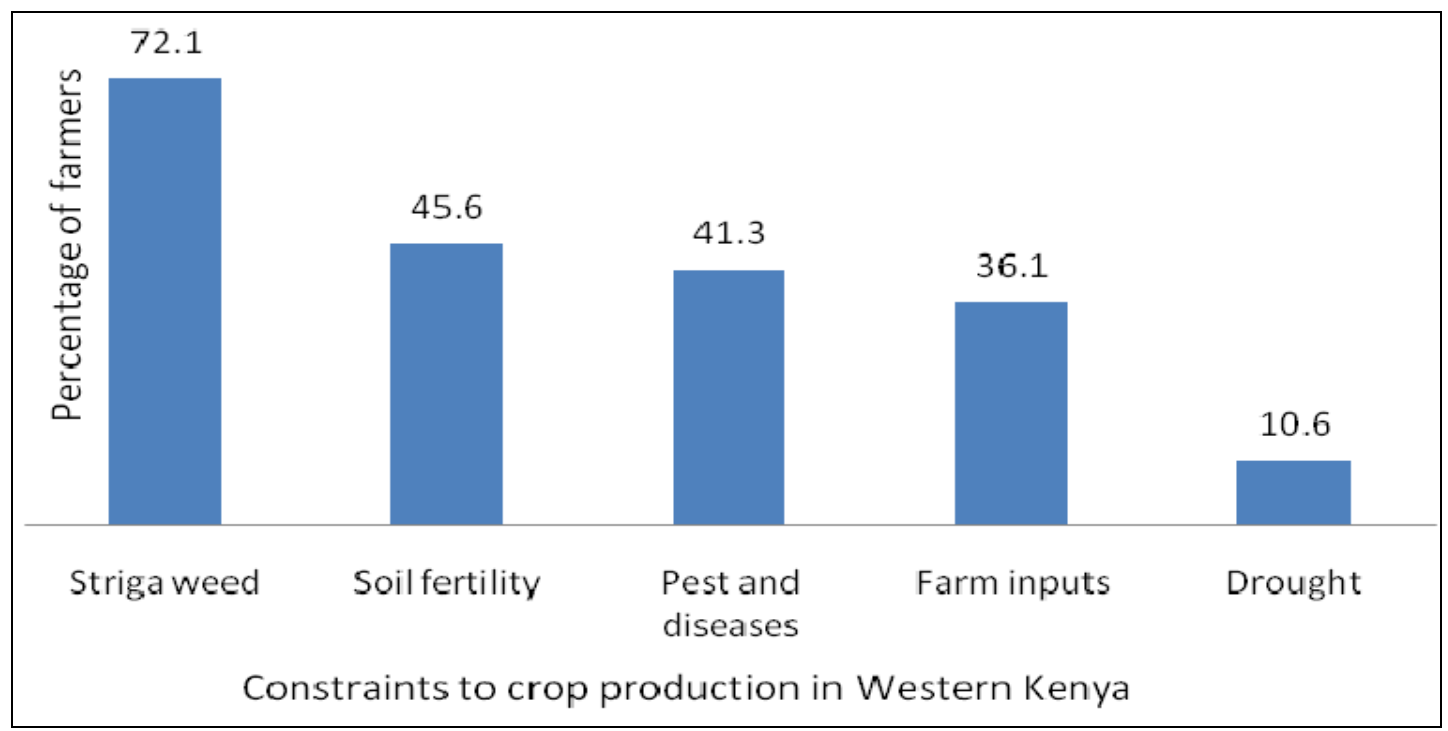

Fig. 3 Factors that hinder maize production in three districts of Western Kenya.

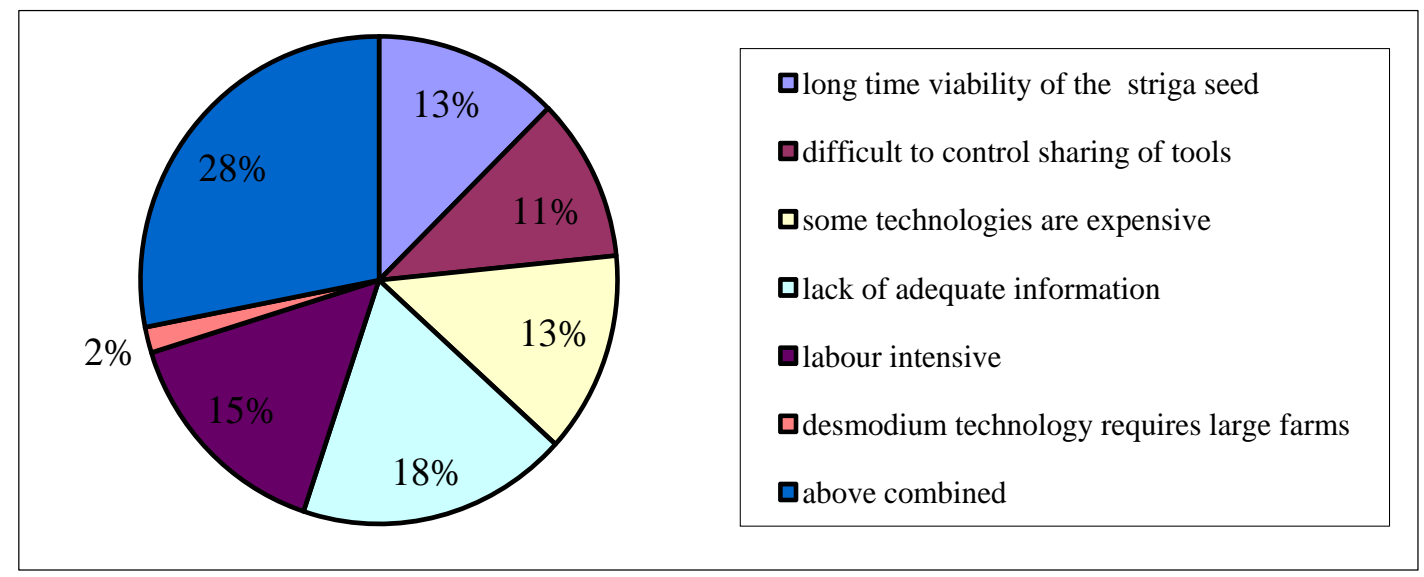

Fig. 4 Farmers' attitudes towards Striga control technologies.

Most of these technologies (weeding and uprooting) required labour (15\%), both hired and family labour for effective control of the weed. Families with few members were unlikely to adopt technologies that were labour intensive unless where they could pay for hired labour. This was also noted in the past research, where large households had the capacity to relax the labour constraints required during the introduction of new technologies [32].

A small number of farmers (2\%) had tried intercropping desmodium with maize but abandoned it because the system required more land, i.e., at least $25 \%$ of an acre to be able to implement effectively. This makes those with small farms to shy away from the technology. The technology required livestock to feed on the desmodium, but given that farmers have small farms with no or very few animals thus the farmers see no use of having desmodium in their farms. Studies by Khan et al. [33, 34] showed that the push and pull strategy for integrated pest management had shown that fodder legumes (Desmodium uncinatum and $D$. intortum) intercropped with maize to repel stem borers reduced Striga infestation in Western Kenya.

\subsection{Striga Control Technologies and Practices in Western Kenya}

About $67.5 \%$ of the farmers did not use the existing 
Striga control technologies (Fig. 5). This is because most farmers preferred to use cheap means rather than engaging in expensive methods that will not provide complete solution. Striga resistance maize seed was used by very few (3.3\%) farmers as opposed to $65.8 \%$ of the farmers who used hybrid non resistant maize seed. Farmers reported that the Striga resistant seeds were only available in few shops. About $2.5 \%$ of the farmers reported that Striga resistant maize seeds had a problem with germination in some areas and with heavy rains the chemical coated on the seeds was easily lost.

According to a survey by Odendo et al. [30], about $80 \%$ of the respondents predominantly grew local varieties, whilst only $20 \%$ grew improved maize varieties, often in addition to the local varieties. The Imazapyr-resistant maize (IRM) technology, though introduced on a large scale in 2004 only $28 \%$ of the sampled households in Western Kenya adopted it and the reasons for this low adoption were unclear [35]. Also, Odendo et al. [27] further indicated that farmers were willing to buy new varieties that were resistant to Striga if availed as long as the price was equal to current market price of other commercial maize seed.

Intercropping was another technology used by farmers, mostly farmers intercropped maize and beans or sometimes with soybeans and groundnuts but this was not done consistently. The intercropping of maize followed by cassava was a technology used by $1.7 \%$ of the respondents. This is because farmers are not persistent in case of any crop failure in the previous season would like to try different crops without examining the root cause of the problem. A study in Ref. [36] showed that intercropping maize with legumes between the rows significantly reduced Striga numbers when compared to maize grown as pure stand. Odhiambo and Ariga [37] further proved that these using on-farm trials which showed that planting maize and beans in the same hole, in Striga infested farms increased maize yields by $78.6 \%$ in Western Kenya.
Push and pull technology, promoted by International Centre of Insect Physiology and Ecology (ICIPE), involves intercropping cereals like maize and sorghum with desmodium. Desmodium roots produce chemicals that stimulate germination of Striga seeds, but then prevent them from attaching successfully to maize roots. The Striga eventually dies and the number of seeds in the soil is also reduced. This was another technology that farmers reported to be using on their farms. Besides, the benefits brought by this technology, few (2.5\%) farmers have adopted it. This has been largely attributed to the big farm that the technology requires and that one is forced to keep livestock in order to enjoy the full benefits of the technology. According to Khan et al. [38], those farmers who adopted push and pull technology had positive impact to Striga control. About $19 \%$ of the farmers in the villages under assessment had adopted "push-pull”, citing the technology's ability to address the major cereal production constraints concurrently as the main attraction.

Traditional technologies (25\%) such as uprooting only, uprooting and burning and uprooting then removing from the field were the most used technologies by farmers to control Striga in maize. These methods were commonly used since they were affordable and easily done. Labor was the only resource required, with farmers depending mostly on family labour as well as hired labour which was sometimes lacking. Due to labour constraints, these traditional technologies were either applied once or twice thus not effective for better yields.

Most (47.5\%) of the farmers used uprooting to get rid of Striga in their farms (Fig. 6). This was for the fact that Striga weed sprouted evenly, to occupy a large area within a short time, after the host plant had emerged from the ground therefore uprooting becomes effective on young Striga seeds. This practice also targets on the weed areas unlike weeding where the digging must be done in areas where weeds have not grown. Weeding was practiced by $4.2 \%$ of the farmers. 


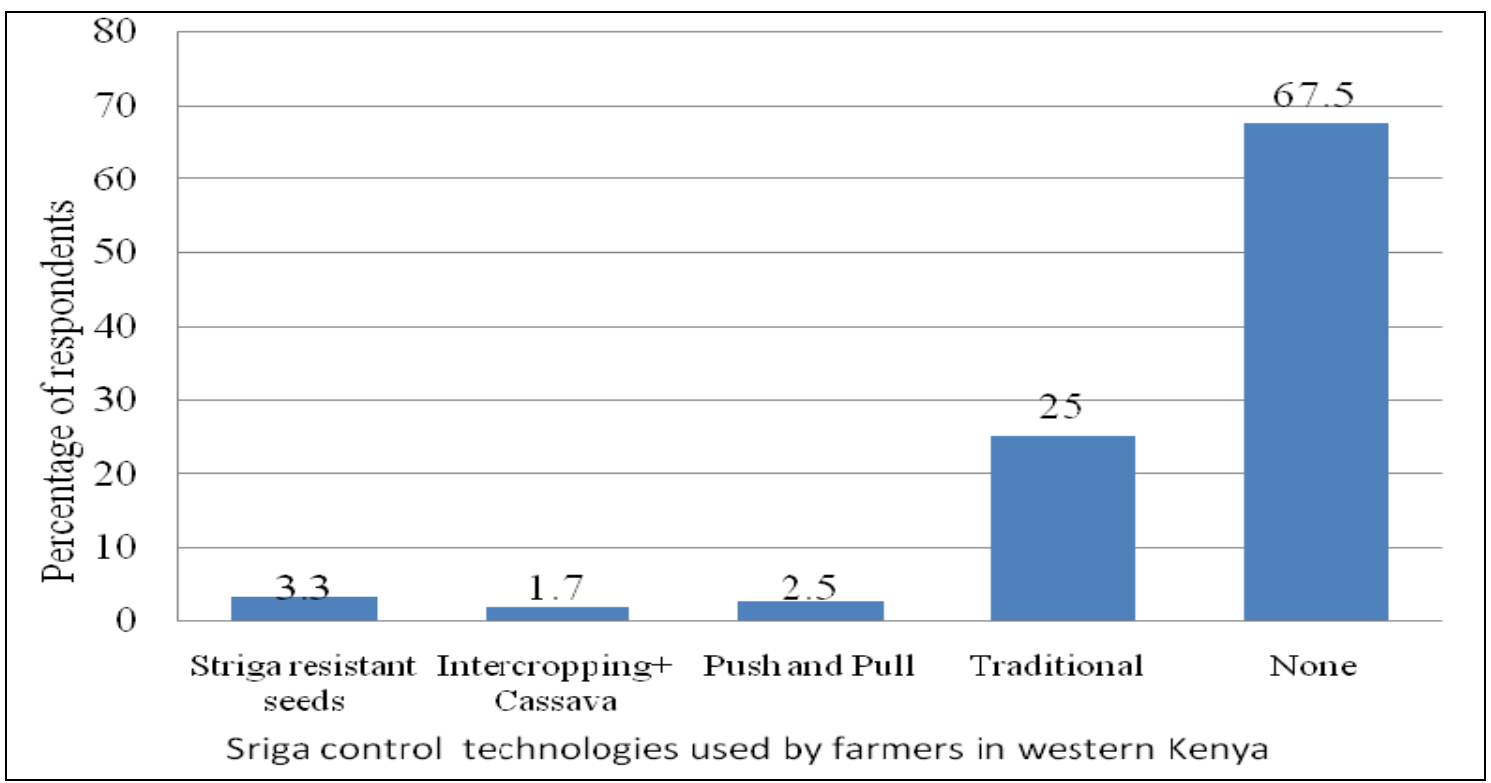

Fig. 5 Striga weed control technologies used by farmers in Western Kenya.

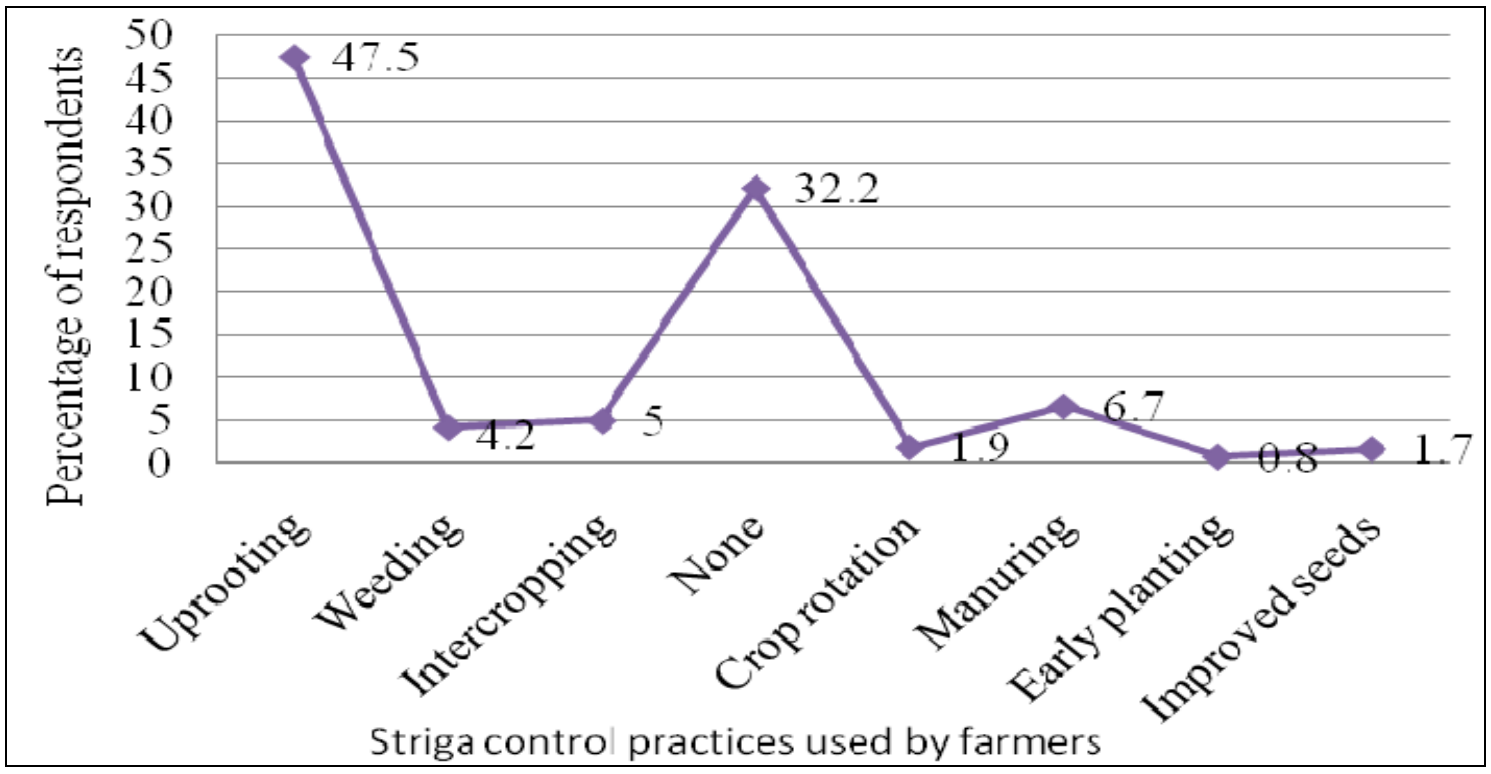

Fig. 6 Farmers' Striga control practices in Western Kenya.

These are mostly farmers who can afford hired labour or have enough family labour.

Other cultural practices were: manuring (6.7\%), intercropping (5\%), crop rotation (1.9\%), improved seeds (1.7\%) and early planting (0.8\%). Manuring and intercropping rated high, this had been contributed through training and field days that farmers do attend. These methods are good remedies to Striga control if integrated with Striga control technologies. The practices can as well improve the soil texture and moisture. A study by Vanlauwe et al. [11] showed that manuring, crop rotation and intercropping also helped in improving soil fertility and enhancing soil health and quality besides weed control.

Early planting was practiced by $0.8 \%$ of the farmers to thwart the growth pattern of the weed so that by the time the weed emerges the crops would have grown to the stage where they were able to resist the effects caused by the weed and thus high yield may be expected. Manyong et al. [21] found uprooting of 

by Smallholder Farmers of Western Kenya

Striga weed to be the most common used (more than $80 \%$ of respondents). Manuring was the second while burning appeared to be an uncommon control method. Suri [39] in their preliminary findings noted that farmers depended on cultural practices like closed season and planting non-host plants.

\section{Conclusions and Recommendations}

The study revealed that farmers perceived Striga weed to be a big menace and major cause of cereal yield losses in their farms. It was also found that the most common source through which farmers got information was village meetings. The meetings comprised of other agendas, thus, do not provide full details of alternative Striga control options. Full adoption of Striga control technologies is likely to increase farm yield, meet family food and income needs and improve soil fertility if access to information include seminars and workshops for farmers, on farm demonstrations and trainings, field visits and use of brochures' translated in local language understood by farmers. Farmers showed different attitudes towards the exiting Striga control technologies and that was the key reason as to why the technologies were not adopted and implemented by farmers. These attitudes included, in order of highest to lowest, lack of adequate information by farmers, followed by labor intensive and expensive technologies, long time dormancy and viability of Striga seeds and large farms needed for the case of push and pull technology.

More than five modern Striga control technologies were in existence in the study area. The results showed that they are not used by farmers but instead farmers prefer using traditional methods which were not result best oriented. The adoption of technologies like, use of Striga resistant maize, intercropping followed by cassava and push and pull technology were to improve farmer's livelihood if fully implemented for a longer period because it brings crops and animals on board. This suits in a mixed farming situation to which most farmers belong.

Despite the farmers' knowledge of the devastating effects of Striga, their control strategies vis-à-vis the many technologies that had been developed to control the weed were limited. Concerted efforts involving researchers, extension agents and private sector are required for wide scale dissemination and adoption of the already developed Striga control technologies. To develop successful Striga control technologies in the area, focus should be on those factors that affect farmer's decision to adopt technology. These factor are technological knowhow, capital/credit access, information barriers and attitudes and social and cultural aspects, putting into consideration escalating poverty and small farms holding, which continue to escalate as a result of farm sub-divisions.

\section{Acknowledgments}

The authors acknowledge Alliance for Green Revolution in Africa (AGRA) for supporting the studies of the first author. Special thanks goes to the International Institute of Tropical Agriculture (IITA) and the Swedish University of Agricultural Sciences (SLU) for their additional support, made possible through funding from Sida/FORMAS and the Swedish Ministry of Foreign Affairs in their special initiative on food security (UD40). Last but not least, tribute to the district agricultural officers in Busia district, administration offices in Kisumu west district, KARI-Alupe in Teso South district and all farmers who voluntarily expressed their views.

\section{References}

[1] M. Odendo, H. De Groote, O.M. Odongo, Assessment of farmers' preferences and constraints to maize production in moist mid altitude zone of Western Kenya, in: 5th International Conference of the African Crop Science Society, Lagos, Nigeria, Oct. 21-26, 2001.

[2] S. Mantel, V.W.P. Van Engelen, Assessment of the impact of water erosion on productivity of maize in Kenya: An integrated modelling approach, Land Degradation and Development 10 (1999) 577-592.

[3] A.A. Kimaro, V.R. Timmer, S.A.O. Chamshama, Y.N. Ngaga, D.A. Kimaro, Competition between maize and 
pigeon-pea in semi-arid Tanzania: Effect on yields and nutrition of crops, Agricultural Ecosystem of Environment 134 (2009) 115-125.

[4] R. Kfir, W.A. Overholt, Z.R. Khan, A. Polaszek, Biology and management of economically important Lepidopteran cereal stem borers in Africa, Annual Review Entomology 47 (2002) 701-731.

[5] A. Oswald, Striga control-technologies and their dissemination, Crop Protection 24 (2005) 333-342.

[6] G. Ejeta, The Striga scourge in Africa: A growing pandemic, in: G. Ejeta, J. Gressel (Eds.), Integrating New Technologies for Striga Control, towards Ending the Witch-Hunt, World Scientific, Singapore, 2002, pp. 3-16.

[7] B.D.S. Salasya, W. Mwangi, H. Verkuijl, M.A. Odendo, J.O. Odenya, An assessment of adoption of seed and fertilizer packages and the role of credit in smallholder production in Kakamega and Vihiga Districts, Kenya, CIMMYT, Kenya Agricultural Research Institute, 1998.

[8] B.D.S. Salasya, Crop production and soil nutrient management: An economic analysis of households in Western and Central Kenya, Ph.D. Thesis, Wageningen University, The Netherlands, 2005.

[9] African Agricultural Technology Foundation (AATF), Empowering African farmers to eradicate Striga from maize croplands, Nairobi, Kenya, 2006, p. 17.

[10] P.L. Woomer, E.J. Mukhwana, G. Odhiambo, D. Okello, M. Omare, N. Sanginga, Striga Control in Western Kenya: Raising Awareness, Containing and Reducing the Infestation and Developing Strategies for Eradication, A report on a collaborative project involving the African Agricultural Technology Foundation (AATF) and the Western Regional Alliance for Technology Evaluation (We RATE), Kenya, 2004, pp. 1-20.

[11] B. Vanlauwe, F. Kanampiu, G.D. Odhiambo, H. De Groote, L.J. Wadhams, Z.R. Khan, Integrated management of Striga hermonthica, stem borers and declining soil fertility in Western Kenya, Field Crops Resource 107 (2008) 102-115.

[12] A.A. Kimaro, V.R. Timmer, S.A.O. Chamshama, Y.N. Ngaga, D.A. Kimaro, Competition between maize and pigeon-pea in semi-arid Tanzania: Effect on yields and nutrition of crops, Agricultural Ecosystem of Environment 134 (2009) 115-125.

[13] J.D. Scholes, M.C. Press, Striga infestation of cereal crops-An unsolved problem in resource limited agriculture, Current Opin. Plant Biology 11 (2008) 180-186.

[14] S.K. Debrah, T. Defoer, M. Bengaly, Integrating farmers' knowledge, attitude and practice in the development of sustainable Striga control interventions in Southern Mali, Agronomy Journal 2 (1998) 35-136.

[15] Z. Mbaga-Semgalawe, Folmer, household adoption of improved soil conservation: The case of the North Pare and West Usambara mountains of Tanzania, Land Use Policy 17 (2000) 321-336.

[16] T. Kalule, Z.R. Khan, G. Bigirwa, J. Alupo, S. Okanya, J.A. Pickett, et al., Farmers' perceptions of importance, control practices and alternative hosts of maize stem borers in Uganda, International Journal of Tropical Insect Science 26 (2006) 71-77.

[17] J.K. Mariara, K.K. Fredrick, The economic impact of climate change, 2007, p. 13.

[18] R. Jaetzold, H. Schimdt, B. Hornetz, C. Shisanya, Natural Conditions and Farm Management Information, Farm Management Handbook of Kenya, Nyanza Province, Vol. 2, 2005.

[19] W.G. Cochran, Sampling Techniques, John Wiley \& Sons, New York, 1977, pp. 74-76.

[20] V.M. Manyong, S.J. Nindi, A.D. Alene, G.D. Odhiambo, G. Omanya, H.D. Mignouna, et al., Farmer perceptions of imazapyr-resistant (ir) maize technology on the control of Striga in Western Kenya, Journal of Development and Agricultural Economics 4 (8) (2008) 245-251.

[21] V.M. Manyong, A.D. Alene, A. Olanrewaju, B. Ayedun, V. Rweyendela, A.S. Wesonga, et al., Baseline Study of Striga Control Using IR Maize in Western Kenya, 2007, pp. 1-16.

[22] J.K. Ndufa, G. Cadisch, C. Poulton, Q. Noordin, B. Vanlauwe, Integrated soil fertility management and poverty traps in Western Kenya, Agricultural Systems 83 (2005) 8-24.

[23] Ministry of Agriculture, Annual reports of Busia, Butere-Mumias and Homa Bay Districts: Ministry of Agriculture, 1999, pp. 6 -38.

[24] SDP (Smallholder Dairy Project), A Participatory Rapid Appraisal (PRA) of Farming Systems in Western Kenya, MOARD/KARI/ILRI/DFID collaborative research project report, ILRI, Nairobi, 2000.

[25] The State of Food and Agriculture, Food and Agriculture Organization (FAO), FAO Agriculture Series 2007, No. 38.

[26] S.J. Hearne, Control the Striga conundrum, Pest Management Science 65 (2009) 603-614.

[27] G.D. Odhiambo, J. Agunda, A. Oswald, Development and diffusion of integrated Striga control practices for small-scale farmers in Western Kenya, African Crop Journal (2001) 126-139.

[28] Cooperative for American Remittances to Europe, Kenya, Task project annual report, Oct. 2001.

[29] R. Hassan, J. Ransom, J. Ojiem, The spatial distribution and farmer's strategies to control striga in maize: Survey results from Kenya, in: Maize for Stress Environments, Proceedings of the Fourth Eastern and Southern Africa Regional Maize Conference, 1995, pp. 250-254. 

by Smallholder Farmers of Western Kenya

[30] M. Odendo, H. De Groote, O. Odongo, P. Oucho, Participatory rural appraisal of farmers' criteria for selection of maize varieties and constraints to maize production in moist-mid altitude zone of Western Kenya-A case study of Butere-Mumias, Busia and Homa Bay Districts, 2002, pp. 2-18.

[31] A. Asfaw, A. Admassie, The role of education on the adoption of chemical fertilizer under different socioeconomic environments in Ethiopia, Agricultural Economics 30 (2004) 215-228.

[32] O.I. Ayuya, J.K. Lagat, J.M. Mironga, Factors influencing potential acceptance and adoption of clean development mechanism projects: Case of carbon trade tree project among small scale farmers in Njoro District, Kenya, Research Journal Environmental Earth Science 3 (3) (2011) 275-285.

[33] Z.R. Khan, J.A. Pickett, J. van den Berg, L.J. Wadhams, C.M. Woodcock, Exploiting chemical ecology and species diversity: Stem borer and striga control for maize and sorghum in Africa, Pest Management Science 56 (2000) 957-962.

[34] Z.R. Khan, A. Hassanali, W. Overholt, T.M. Khamis, A.M. Hooper, J.A. Pickett, Control of witch weed Striga hermonthica by intercropping with Desmodium spp. and the mechanism defined as allelopathic, Journal of Chemical Ecology 28 (2002) 1871-1885.

[35] D.B. Mignouna, V.M. Manyong, K.D.S. Mutabazi, E.M. Senkondo, Determinants of adopting imazapyr-resistant maize for Striga control in Western Kenya: A double-hurdle approach, Journal of Development and Agricultural Economics 3 (11) (2011) 572-580.

[36] G.D. Odhiambo, J.K. Ransom, Effect of Dicamba on the control of Striga hermontheca in maize in Western Kenya, African Crop Journal 1 (2001) 105-110.

[37] G.D. Odhiambo, E.S. Ariga, Effect of intercropping maize and beans on Striga incidence and grain yield, in: Seventh Eastern and Southern Africa Regional Maize Conference, Feb. 11-15, 2004, pp. 183-186.

[38] Z.R. Khan, C.A.O. Midega, A. Hassanali, J.A. Pickett, L.J. Wadhams, Assessment of different legumes for the control of Striga hermonthica in maize and sorghum, Crop Science 47 (2007) 730-736.

[39] T. Suri, Selection and comparative advantage in technology adoption, Econometrical 79 (1) (2011) 159-209. 